\title{
ОБРАБАТЫВАЮЩИЙ ЦЕНТР
} С АВТОМАТИЧЕСКОЙ СМЕНОЙ ИНСТРУМЕНТА \section{MACHINING CENTER WITH AUTOMATIC TOOL CHANGE}

\author{
И.В.Яминский', 2, з, д.ф.-м.н., проф., генеральный директор Центра перспективных технологий, директор \\ Энергоэффективных технологий (ORCID: 0000-0001-8731-3947), А.И.Ахметова ${ }^{1,2,3}$, инженер НИИ ФХБ имени \\ А.Н.Бепозерского МГУ, ведущий специалист Центра перспективных технологий и Энергоэффективных \\ технологий (ORCID: 0000-0001-6363-8202) / yaminsky@nanoscopy.ru \\ I.V.Yaminsky', 2,3, Doctor of Sc. (Physics and Mathematics), Prof., Director of Advanced Technologies Center, Director of \\ Energy Efficient Technologies, (ORCID: 0000-0001-8737-3947), A.I.Akhmetoval, 2,3, Engineer of A.N.Belozersky Institute \\ of Physico-Chemical Biology, Leading Specialist of Advanced Technologies Center and of Energy Efficient Technologies, \\ (ORCID: 0000-0001-6363-8202)
}

\section{DOI: 10.22184/1993-8578.2019.12.5.276.279}

Получено: 02.08.2019г.

\begin{abstract}
Разработка малогабаритного обрабатывающего центра с возможностями промышленного фрезерного станка становится хорошей альтернативой продуктам иностранных концернов в области учебного оборудования. Большое количество разнообразных операций, выполняемых с одной установки заготовки в станок, и автоматическая замена инструмента без участия оператора повышают точность обработки, снижают стоимость изделий, экономят время и являются наглядным пособием для участников обучающих курсов по работе с оборудованием, максимально приближенным по функционалу к полноразмерным промышленным решениям.

Development of a small-size machining center having the abilities of an industrial milling machine presents a real alternative to the foreign products in the field of educational equipment. Such machining center enables to perform a great number of operations and the automatic change of tools after installing one blank without the intervention of an operator in order to improve accuracy of measurements, save time and serve as a visual aid in practical courses devoted to studying the equipment operation which reflects the maximum realistic conditions of manufacturing in full-size industrial solutions.
\end{abstract}

танкостроение в Российской Федерации является развивающейся и перспективной отраслью промышленности. Уникальность создаваемой платформы для механообработки состоит в разработке малогабаритного высокопроизводительного фрезерного станка с автоматической сменой инструмента, с интегрированными технологиями 3D-сканирования и лазерной гравировки для цифрового производства. За счет компьютерного моделирования основных элементов при проектировании достигаются наивысшие параметры скорости и точности позиционирования подвижных частей центра, эффективность использования ресурсов при изготовлении, энергоемкость, стабильность, снижение материалоемкости, эргономичность, удобство эксплуатации за счет современного программного обеспечения обрабатывающего центра с автоматической сменой инструмента.

Разрабатываемый обрабатывающий центр АТС "Индустрия 4.0" предназначен для удовлетворения потребностей мелкосерийного производства, прототипирования в лабораториях, в опытных конструкторских отделах, для функционирования в учебных центрах. Благодаря высокой точности и компактности обрабатывающий

\footnotetext{
МГУ имени М.В.Ломоносова / Lomonosov Moscow State University, Physical and Chemical departments.

ООО НПП "Центр перспективных технологий" / Advanced Technologies Center.

ООО "Энергоэффективные технологии" / Energy Efficient Technologies.
} 
центр может найти широкое применение при изготовлении деталей и узлов для научных приборов и технологических установок, перспективных для использования в современной наноиндустрии.

Отметим уникальные черты разрабатываемого обрабатывающего центра с автоматической сменой инструмента.

1. Размер рабочей области превышает современные аналоги на российском рынке при схожих габаритных размерах, массе и точности обработки. Площадь ограничена бесконтактными датчиками, что позволяет обеспечить безопасность работы систем станка и исключить возможность возникновения аварийных ситуаций, связанных с нежелательным контактом исполнительных устройств с силовыми элементами конструкции обрабатывающего центра.

2. Уникальное программное обеспечение, разрабатываемое специально под нужды пользователя и для наиболее эффективного функционирования станка. ПО обрабатывающего центра обеспечивает взаимодействие со всеми системами станка, отслеживая их позиционирование и обеспечивая безопасный рабочий процесс.

3. Наличие автоматической смены инструмента без участия оператора станка. Данное решение позволяет расширить область задач, которые могут быть решены с помощью обрабатывающего центра, ускорить процесс обработки изделия и исключить человеческий фактор из процесса обработки. Автоматическая смена инструмента позволяет также существенно повысить точность изготовления деталей, поскольку каждый раз при использовании нового инструмента для обработки детали отпадает необходимость в его дополнительной юстировке.

4. Оснащение обрабатывающего центра модулями для лазерной обработки и 3D-сканирования существенно расширяет диапазон решаемых в ходе проектирования и прототипирования задач.

5. Массо-габаритные характеристики обрабатывающего центра обеспечивают его транспортабельность и упрощают его размещение в пределах небольших производственных помещений, в образовательных центрах и лабораториях.
M achine tool building is a prospective and developing industry of the Russian Federation. Development of smallsize and high-capacity milling machine with automatic change of tools and integrated 3D scanning technologies with laser engraving for digital production is the unique feature of the machining processing platform.

Highest parameters of the speed and positioning of the moving parts of the center, efficiency of resource usage, power capacity, stability, ergonomics and convenient operation due to modern software are achieved by using computer simulation of the processing center with automatic tool change model. ATC Industry 4.0 machining center to be developed is intended for small lot production needs and prototyping in laboratories, engineering offices and training centers. It may be useful when manufacturing parts and units of scientific instruments and technological installations and is perspective for modern nanoindustry because of high accuracy and compactness. This machining center with automatic change of tools has unique features as follows:

1. The working area exceeds the similar analogs on the Russian market though the overall dimensions, weight and machining accuracy are the same. It has contactless sensors to provide safe operation of the machine systems and exclude a probability of hazardous situations connected with the undesirable contacts between the working parts and power elements of the center.

2. The unique software customized for user needs and high efficiency of center operation. The machining center software coordinates operation of all center systems by tracing positioning and ensuring safety of the process.
3. Ability to change tools without intervention of the operator. This feature makes it possible to solve more problems using the machining center and to speed up the parts processing in order to exclude the human factor in the machining cycle. Automatic tools change permits to improve the accuracy of the machining at every tool change because the additional adjustment is not necessary.

4. Fitting up of the center with additional modules for laser engraving and 3D scanning considerably spreads the range of task solved during the design and prototyping.

5. Weight and dimensions of the center make it easy to transport and install the center inside small production space, training institutions and laboratories.

During the development of the machining center, preliminary design was carried out 


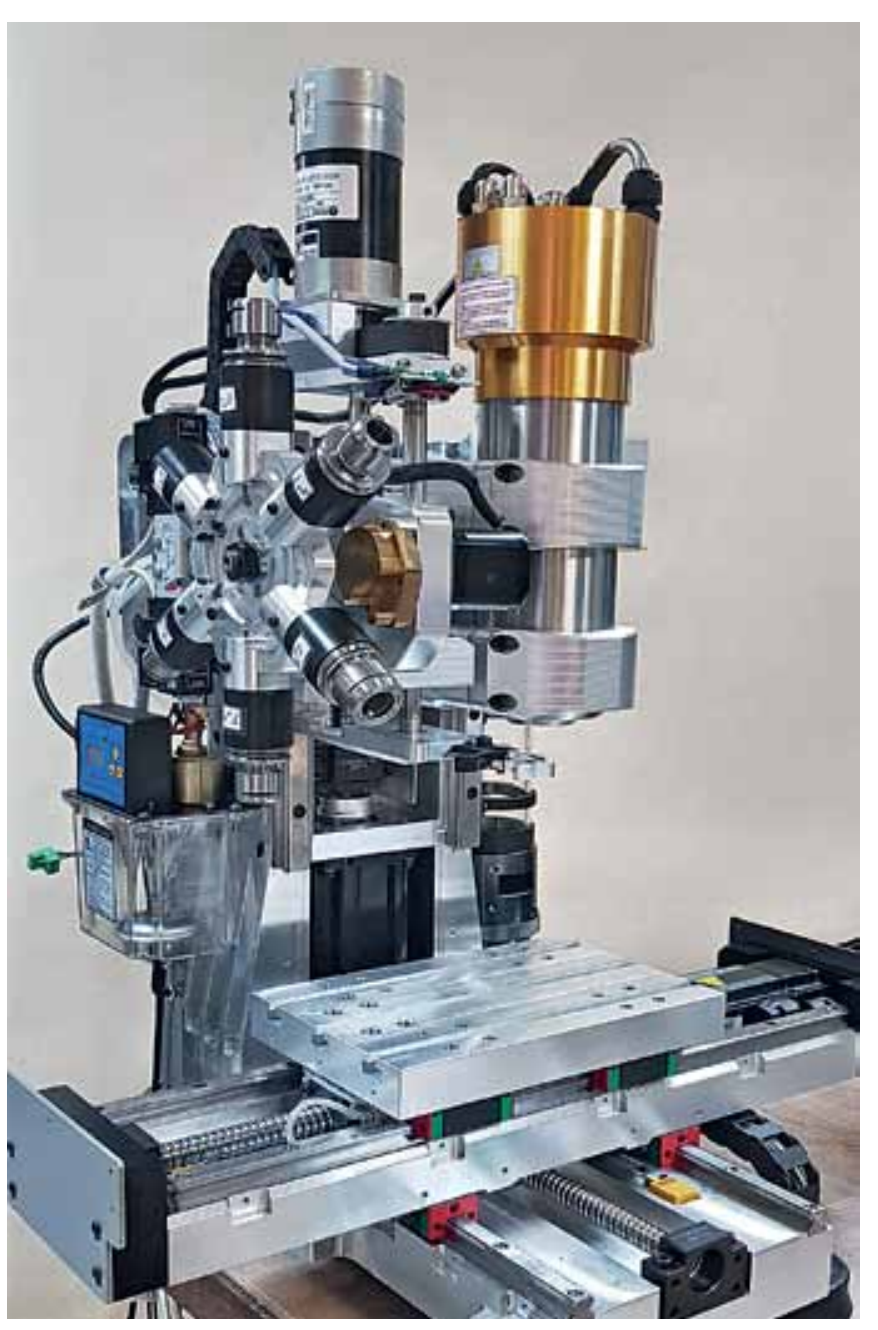

Puс.1. Обрабатывающий центр "АТС Индустрия 4.0" Fig.1. ATC Industry 4.0 machining center
При разработке обрабатывающего центра предварительно было проведено проектирование в САПР-системе SolidWorks. Данный метод разработки и решения задач, возникающих в ходе процесса проектирования, позволяет предвидеть проблемы, которые могут возникнуть на этапе сборки и испытания обрабатывающего центра, определить количество и тип используемого для производства материала, а также заранее предусмотреть проблемы, возникающие в процессе сборки, например, подвод рабочего инструмента, использование оснастки в необходимых узлах сборки, расположение крепежных соединений. При разработке 3D-манипулятора используются имеющиеся оригинальные разработки по нанопозиционированию, применяемые в фрезерно-гравировальных станках и сканирующих зондовых микроскопах [1, 2].

Основные технические параметры рабочего макета обрабатывающего центра "АТС Индустрия 4.0":

- скорость холостых перемещений по осям - не менее 5,5 м/мин;

- точность позиционирования - 9 мкм;

- повторяемость- 5 мкм;

- время смены инструмента-9 с;

- время разгона шпинделя: 0-24000 об/мин - 7,5 c;

- количество осей перемещения: 3 линейные оси с возможностью установки 4-й дополнительной оси.

Основные технические параметры рабочего макета 3D-манипулятора: in the SolidWorks CAD system. This method allows of predicting the problems which may occur while assembling and testing of the machining center and determining the type and quantity of the necessary materials. Moreover, the important solutions of tools advance and fittings usage and configuration of mountings may be conveniently foreseen by application of the method mentioned above. Original developments connected with nano-positioning applied previously in operation of milling and engraving machines and probe microscopy were used for 3D manipulator development [1, 2].

Basic technical parameters of ATC machining center Industry 4.0 working prototype are:

- overlap processing rate along the axis - at least $5.5 \mathrm{~m} / \mathrm{min}$;

- positioning accuracy - $9 \mu$;

- repeatable accuracy - $5 \mu$ Tool-to-tool changing time - 9 sec;

- main spindle acceleration time from 0 to $24,000 \mathrm{r} / \mathrm{min}-7.5 \mathrm{sec}$;

- number of displacement axes: 3 linear axes with ability to add the additional $4^{\text {th }}$ axis.

Basic technical parameters of 3D manipulator working prototype:
- displacement accuracy within 1-10 nm;

- extremely precise machining with resolution in a sample plane $-0.25 \mathrm{~nm}^{-}$and perpendicular to a sample $-0.1 \mathrm{~nm}$.

The milling machining center with automatic change of tools and 3D precise manipulator is intended for the individual usage, prototyping in factories and plants, construction departments and training facilities. The solutions proposed in this project enable to obtain the best possible technical parameters at relatively low cost which make the milling machining centers on a par with 
- точность перемещения в диапазоне 1-10 нм;

- сверхточная обработка с разрешением в плоскости образца - 0,25 нм и по нормали к образцу - 0,1 нм. Фрезерный обрабатывающий центр с автоматической сменой инструмента и прецизионным 3D-манипулятором предназначен для индивидуального использования, реализации разработок и прототипирования на фабриках и заводах, в опытных конструкторских отделах, а также в образовательных учреждениях. Предлагаемые в проекте решения позволят при относительно низкой стоимости получить самые высокие технические параметры, не уступающие промышленным сериям малогабаритных станков с ЧПу зарубежных концернов. Благодаря своей мобильности, модульной конструкции и многофункциональности малогабаритные обрабатывающие центры особенно востребованы в общеобразовательных учреждениях в качестве интерактивного обучающего комплекса для детей [3].

Созданный фрезерный обрабатывающий центр "АТС Индустрия 4.0" эффективно использовался нами при изготовлении деталей сканирующего капиллярного микроскопа - проточной жидкостной ячейки, держателя зонда, крепления электродов и др.

Этот центр стал продолжением станков серии АТС, совместно разрабатываемых высокотехнологичными компаниями ООО НПП "Центр перспективных технологий" и ООО "Энергоэффективные технологии" при активном участии физического и химического факультетов МГу имени М.В.Ломоносова. Информация об этих разработках находится в открытом доступе на сайтах www.ATCindustry.com и www.2ETechnologies.com. Станки серии АТС активно применяются в Центре молодежного инновационного творчества "Нанотехнологии" (www.startinnovation.com) как в образовательных, так и производственных целях.

Работы по изготовлению обрабатывающего центра выполнены при поддержке Фонда содействия инновациям (договор № 422ГРНТИС5/44715). Изготовление деталей капиялярного микроскопа с использованием этих деталей и последующее исследование выполнены при финансовой поддержке РФФИ в рамках научного проекта № 17-52-560001.

Авторы выражают искреннюю благодарность Департаменту предпринимательства и инновационного развития города Москвы и Министерству экономического развития Российской Федеращии (договор № 8/3-63ин-16 om 22.08.16) за неоценимую помощь.

\section{ЛИТЕРATУPA / REFERENCE}

6. Akhmetova A., Belov J., Meshkov G., Yaminsky I. Systems of 3d-positioning in the precise processing of materials. NANOINDUSTRY, 71 (1): 102-104, 2017.

7. Yaminsky I. V. The secret of a cricket for mashed potatoes. NANOINDUSTRY, 73 (3): 72-75, 2017.

8. Akhmetova A., Belov J., Yaminsky I. Modular multi-axis machining center for nanoindustry. NANOINDUSTRY, 68 (6): 82-84, 2016. the mass-produced small-size CNC machines made by foreign manufacturers. Due to smallsize, modular construction and multi-functionality these machining centers are especially required in general training facilities as interactive complexes for children [3]. We efficiently used the ATC Industry 4.0 milling machining center to prepare parts of the scanning capillary microscope (flowing fluid cell, probe fastenings, electrode holds, etc.)

This center is the continuation of ATC family machine tools developed by such hightech companies as Advanced
Technologies Center and Energy Efficient Technologies together with specialists of the Physical and Chemical Departments of Lomonosov Moscow State University. Information of these developments is available free on www. ATCindustry. com and www.2ETechnologies. com. ATC family machines are widely used in the Centre for Youth Innovative Creativity "Nanotechnologies" (www.startinnovation.com) for training and production aims.

The works on manufacturing the machining center was accomplished with the support of the Fund for the Promotion of Innovation Contract No. 422GRNTIS5 / 44715. The manufacture of the capillary microscope parts and subsequent research using these parts was carried out with the financial support of the Russian Foundation for Basic Research in the framework of scientific project No. 17-52-560001.

The authors are sincerely grateful to the Department of Entrepreneurship and Innovative Development of the City of Moscow and the Ministry of Economic Development of the Russian Federation (agreement No. 8 / 3-63in16 of 08.22.16) for their invaluable assistance. 